I thank Professor G. A. D. Haslewood for helpful advice and encouragement, and Mr. E. Condillac for technical help. This work was supported by a grant from the Medical Research Council.

\section{References}

Ament, M. E., Shimoda, S. S., Saunders, D. R., and Rubin, C. E. (1971). Gastroenterology, 60, 637.

Anderson, I. G., and Haslewood, G. A. D. (1970). Biochemical fournal, 116,

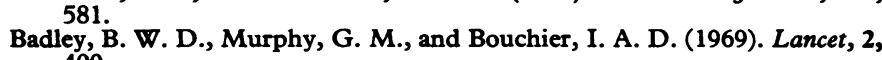
400.

Cheney, F. E., Burke, V., Clark, M. L., and Senior, J. R. (1970). Proceedings of the Society for Experimental Biology, 133, 212

Clark, M. L., Lanz, H. L., and Senior, J. R. (1969). Fournal of Clinical Investigation, 48, 1587.

Dawson, A. M., and Isselbacher, K. J. (1960). Fournal of Clinical Investigation, 39, 730.

Dietschy, J. M., Salamon, H. S., and Siperstein, M. D. (1966). Fournal of Clinical Investigation, 45, 832 .
Donaldson, R. M. (1965). fournal of Clinical Investigation, 44, 1815.

Eneroth, P. (1963). Fournal of Lipid Research, 4, 11.

Gallagher, N. D., Webb, J. P. W., and Dawson, A. M. (1968). Gut, 9, 561. Hislop, I. G., Hofmann, A. F., and Schoenfield, L. J. (1967). Fournal of Clinical Investigation, 46, 1070

Hofmann, A. F., and Borgstrom, B. (1964). Fournal of Clinical Investigation, 43, 247.

Iwata, T., and Yamasaki, K. (1964). Fournal of Biochemistry, 56, 424.

Kim, Y. S., Spritz, N., Blum, M., Terz, J., and Sherlock, P. (1966). Fournal of Clinical Investigation, 45, 956

Kjaerheim, A., and Nygaard, K. (1968). Scandinavian fournal of Gastro-

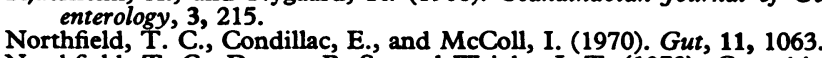

Northfield, T. C., Drasar, B. S., and Wright, J. T. (1973). Gut.. 14, 341.

Northfield, T. C., Drasar, B. S., and Wright, J. T. (1973). Gut.. 14, 341.

Paulk, E. A., and Farrar, W. E. (1964). American fournal of Medicine, 37, 473.

Rubin, C. E., and Dobbins, W. O. (1965). Gastroenterology, 49, 676.

Small, D. M. (1971). In The Bile Acids, ed. P. P. Nair and D. Kritchevsky, vol. I, p. 289 . New York, Plenum Press.

Tabaqchali, S., and Booth, C. C. (1966). Lancet, 2, 12.

Tabaqchali, S., Hatzioannou, J., and Booth, C. C.' (1968). Lancet, 2, 12.

Wiggins, H. W., Cook, H. B., and McLeod, G. M. (1967). Tijdschrift voor Gastro-enterologie, 10, 64 .

\title{
Quantitative Skeletal Histology in Untreated End-stage Renal Failure
}

\author{
JOAN P. INGHAM, JOHN H. STEWART, SOLOMON POSEN
}

British Medical fournal, 1973, 2, 745-748

\section{Summary}

Forty-six patients with end-stage renal failure were subjected to iliac crest biopsy before the initiation of a dialysis programme and regardless of the presence of skeletal symptoms. Quantitative studies of undecalcified sections showed osteoporosis in 11 patients, osteosclerosis in 10, and osteomalacia (alone or in combination with other lesions) in 14. Semiquantitative studies showed osteitis fibrosa (alone or in combination with other lesions) in 29. The various abnormalities occurred alone or in combination with one another and, to a large extent, independently of serum biochemistry.

Radiological examination failed to diagnose the histological abnormality in 12 of 13 patients with osteomalacia and in 10 of 25 patients with osteitis fibrosa. These abnormalities were commoner in women, in patients with pyelonephritis, and in patients with documented renal failure of long standing. Bone volume changes could not be correlated with any clinical parameters.

Skeletal findings in untreated patients should be taken into account when the effects of chronic dialysis or renal transplantation or both are being considered.

\section{Introduction}

The association between renal failure and skeletal disease has been recognized for almost a century (Lucas, 1883) and the literature contains many reviews of the subject (Claireaux, 1953; Stanbury, 1957, 1968; Kleeman et al., 1969; Katz et al., 1969). In recent years the emphasis has shifted to the study of

\footnotetext{
Department of Medicine and the Immunology and Renal Unit, Sydney Hospital, Sydney, N.S.W., Australia, 2001

JOAN P. INGHAM, M.B., F.R.A.C.P., Research Fellow, Department of Medicine

JOHN H. STEWART, M.B., F.R.A.C.P., Associate Director, Medical Research Department

skeletal lesions among patients receiving chronic haemodialysis (O'Riordan et al., 1970; Jowsey et al., 1972) and among recipients of renal homografts (Hall et al., 1969; Johnson et al., 1971; Harrington et al., 1971). As such patients are likely to have composite lesions (those due to their renal failure and those due to treatment) we have attempted to identify, by quantitative methods, what abnormalities were present before the commencement of a dialysis/transplantation programme.

\section{Patients and Methods}

Forty-six patients were subjected to iliac crest biopsy at the time of the creation of an arteriovenous fistula and before the initiation of maintenance haemodialysis for end-stage renal failure. All had serum creatinine levels in excess of $12 \mathrm{mg} / 100 \mathrm{ml}$ and none had undergone more than two peritoneal dialyses before the performance of bone biopsy. There was no selection of patients according to skeletal symptoms (which were present in two patients) or according to serum biochemistry (other than nitrogenous retention).

The various underlying renal disorders are shown in table $I$. There were 18 patients ( 15 male, 3 female) with chronic glomerulonephritis. This diagnosis was made on the basis of histological findings (Heptinstall, 1968) in nine cases and on the basis of a characteristic history of acute glomerulonephritis and/or the nephrotic syndrome before the onset of renal failure in three cases. In six patients the diagnosis of chronic glomerulonephritis was based on normal pyelographic appearances, the

TABLE I-Underlying Renal Disorders in 46 Patients Subjected to Bone Biopsy

\begin{tabular}{|c|c|c|c|c|c|}
\hline & & M. & F. & $\underset{\text { (years) }}{\text { Mean Age }}$ & $\begin{array}{c}\text { Mean Duration of } \\
\text { Renal Failure* } \\
\text { (months) }\end{array}$ \\
\hline 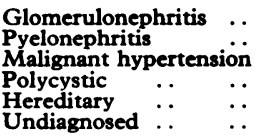 & $\begin{array}{l}. \\
\because \\
\because \\
\because\end{array}$ & $\begin{array}{r}15 \\
2 \\
4 \\
0 \\
0 \\
0\end{array}$ & $\begin{array}{r}3 \\
16 \\
2 \\
2 \\
1 \\
1\end{array}$ & $\begin{array}{l}36 \\
34 \\
31 \\
53 \\
46 \\
42\end{array}$ & $\begin{array}{r}38 \\
33 \\
5 \\
19 \\
48 \\
25\end{array}$ \\
\hline Total & & 21 & 25 & 38 & 31 \\
\hline
\end{tabular}

* Renal failure was dated from the time of the first documented blood urea nitrogen of $31 \mathrm{mg} / 100 \mathrm{ml}$ or more. 
presence of symmetrical kidneys with smooth outlines, and proteinuria (at least $100 \mathrm{mg} / 100 \mathrm{ml}$ ) on five or more occasions.

There were 18 patients ( 2 male, 16 female) suffering from chronic pyelonephritis. This diagnosis was based on irregular renal outlines and calyceal "clubbing" (British Medical fournal, 1971) in each case, and the histology was believed to be characteristic (Heptinstall, 1968) in each of the 10 cases where histological material was available for examination. Thirteen of the 18 patients with pyelonephritis gave a history of a "heavy" (Lavan et al., 1966; Blackman et al., 1967) consumption of analgesics, 10 had infected urines (Jennis et al., 1970) on three or more occasions, two had radiographic evidence of ureteric reflux, and in one "patulous" ureteric orifices were noted at cystoscopy though reflux was not seen. The mean age of the pyelonephritic patients was 3.7 years greater than that of the patients with glomerulonephritis.

Six patients had malignant hypertension presumed to be "essential" on the basis of an absence of demonstrable renal, vascular, or endocrine causes. The renal histology was characteristic (Heptinstall, 1968) in four of these patients who underwent nephrectomy. The other two had normal-sized kidneys with smooth outlines and little. or no proteinuria. Four of these six patients had a documented history of hypertension of less than one year and the mean duration of renal failure was five months in this group.

There were two patients with polycystic kidneys, one patient with hereditary nephropathy and deafness (Perkoff, 1967), and one with features of both glomerulonephritis and pyelonephritis. The mean age of the 21 males in the series was 33.3 years, that of the 25 females $41 \cdot 2$ years.

At the time of writing 15 patients were dead (10 of these had pyelonephritis), 19 had been successfully transplanted with a cadaver kidney, and 12 were receiving maintenance dialysis either permanently or while awaiting a kidney.

Iliac crest biopsies (Hocking, 1964) were performed in all patients within seven days of creation of their arteriovenous shunts and in most patients at the actual time of construction of the shunt. The biopsy material (a cylindrical specimen $1-1 \frac{1}{2} \mathrm{~cm}$ long by $3 \mathrm{~mm}$ in diameter and consisting mainly of cancellous bone) was processed according to methods previously described from this unit (Garrick et al., 1971, 1972). Undecalcified sections were examined quantitatively to determine the proportion of a given area occupied by bone (the "total bone index") and the proportion occupied by uncalcified bone (the "osteoid index"). Normal iliac crest material (Garrick et al., 1972) had a mean bone index of $25.9 \pm 2.0 \%$ in 16 males with a mean age of

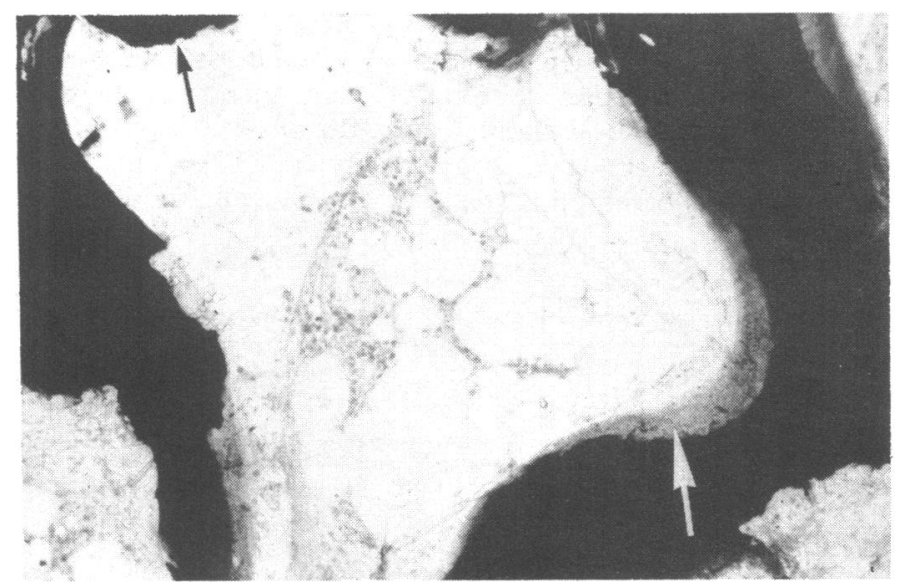

FIG. 1-Osteitis fibrosa and osteomalacia co-existing in a patient with endstage renal failure. Black arrow points to the "scalloped" areas of osteitis fibrosa, white arrow points to thick osteoid seam. (Von Kossa and toluidine
blue stains. $\times 40$.)
33.8 years and $24.4 \pm 3.8 \%$ in 16 females with a mean age of 43.9 years. In normal subjects of both sexes the osteoid index was less than $0.7 \%$ in all cases.

Osteoporosis was diagnosed when the total bone index was $21.8 \%$ or less in males and $16.7 \%$ or less in females. "Osteosclerosis" was diagnosed when the total bone index was $30.0 \%$ or more in males and $32.1 \%$ or more in females. Osteomalacia was diagnosed in either sex when the osteoid index was $0.8 \%$ or more, while "severe" osteomalacia was defined as an osteoid index of $2 \cdot 1 \%$ or more. Osteitis fibrosa was arbitrarily said to be absent, mild, or severe according to the number of identifiable areas of "scalloping" (fig. 1).

Biochemical determinations were performed according to methods previously described (Jennis et al., 1970; Pratley et al., 1973). When the serum alkaline phosphatase was raised to 18 King-Armstrong units or more per $100 \mathrm{ml}$, the tissue origin of this enzyme was determined by heat denaturation (Posen et al., 1965). $X$-ray pictures of the hands, clavicles, lumbar spine, skull, and pelvis were taken at the time of biopsy in 37 patients.

The radiological changes of osteoporosis (Siegelman, 1970), osteomalacia (Steinbach et al., 1964), osteitis fibrosa (Steinbach et al., 1961), and osteosclerosis (Cohen et al., 1970; Shapiro, 1971) were specifically looked for and the radiological findings were compared with the histological findings.

\section{Results}

The bone indices of the patients were compared with those of normal controls (Garrick et al., 1971, 1972), matched for sex and age. The mean bone volumes of the patients with end-stage renal failure were almost identical with those of the normal subjects but the range was much wider among the patients.

One of the patients with histological osteoporosis had received steroid therapy before entering the programme while two of the 10 osteosclerotic patients had associated osteomalacia. There was no demonstrable correlation between the bone index and the presence or absence of osteomalacia and osteitis fibrosa or between the bone index and the duration of documented renal failure.

The prevalence of qualitative changes (osteomalacia and osteitis fibrosa) in males and females is shown in table II. Nineteen of the 25 females had histological hyperparathyroidism compared with 10 of the 21 males. Table II also shows that osteitis fibrosa (alone or in combination with other lesions) was twice as common as osteomalacia (alone or in combination with other lesions).

TABLE II-Prevalence of Osteomalacia and Osteitis Fibrosa in 46 Males and Females with End-stage Renal Failure

\begin{tabular}{c|c|c|c|c}
\hline & $\begin{array}{c}\text { Normal Bone } \\
\text { or Volume } \\
\text { Changes Only }\end{array}$ & Osteomalacia & $\begin{array}{c}\text { Osteomalacia } \\
\text { +Osteitis } \\
\text { Fibrosa }\end{array}$ & $\begin{array}{c}\text { Osteitis } \\
\text { Fibrosa }\end{array}$ \\
\hline Males (21) $\ldots$ & 10 & 1 & 4 & 6 \\
\hline Females (25) $\ldots$ & 3 & 3 & 6 & 13 \\
\hline Total & 13 & 4 & 10 & 19 \\
\hline
\end{tabular}

Six patients with essential hypertension and six of the glomerulonephritics were free from osteomalacia and osteitis fibrosa while only one of the patients with pyelonephritis failed to show either osteomalacia or osteitis fibrosa (or both) (table III). No correlation could be established in individual patients between the severity of osteomalacia and that of osteitis fibrosa.

Half the patients $(12 / 25)$ whose renal failure had been present for 12 months or less showed neither osteomalacia nor osteitis fibrosa (table IV). Only one patient whose renal failure had been present for 13 months or more had neither of these lesions. Osteomalacia was present as the only lesion in four 
TABLE III-Osteomalacia and Osteitis Fibrosa in 46 Patients with Renal Failure

\begin{tabular}{|c|c|c|c|c|c|}
\hline Renal Lesion & No. & $\begin{array}{l}\text { Normal Bone } \\
\text { or Volume } \\
\text { Changes Only }\end{array}$ & Osteomalacia & $\begin{array}{c}\text { Osteomalacia } \\
+ \text { Osteitis } \\
\text { Fibrosa }\end{array}$ & $\begin{array}{l}\text { Osteitis } \\
\text { Fibrosa }\end{array}$ \\
\hline $\begin{array}{ll}\text { Glomerulonephritis .. } \\
\text { Pyelonephritis } \\
\text { Malignant } \\
\begin{array}{l}\text { hypertension } \\
\text { Miscellaneous }\end{array} & \ldots \\
& \text {. }\end{array}$ & $\begin{array}{r}18 \\
18 \\
6 \\
4\end{array}$ & $\begin{array}{l}6 \\
1 \\
6 \\
\end{array}$ & $\begin{array}{r}1 \\
3 \\
- \\
\end{array}$ & $\begin{array}{r}3 \\
6 \\
-1\end{array}$ & $\begin{array}{r}8 \\
8 \\
-3\end{array}$ \\
\hline Total & 46 & 13 & 4 & 10 & 19 \\
\hline
\end{tabular}

TABLE IV-Correlation between Duration of Documented Renal Failure and Skeletal Lesions

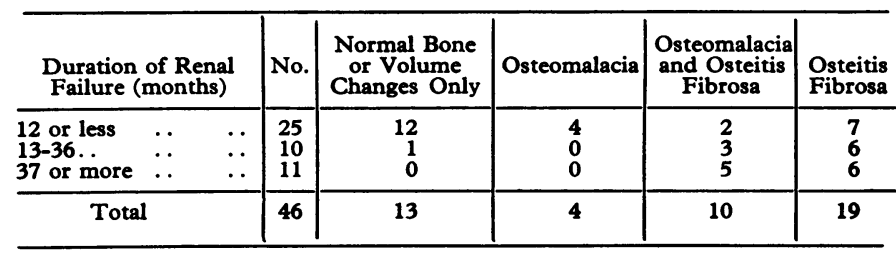

TABLE V-Correlation between Radiological and Histological Lesions

\begin{tabular}{|c|c|c|c|c|c|c|}
\hline \multirow[b]{2}{*}{$X$-ray Findings } & & \multirow[b]{2}{*}{ No. } & \multicolumn{4}{|c|}{ Histological Findings } \\
\hline & & & $\begin{array}{l}\text { Normal Bone } \\
\text { or Volume } \\
\text { Changes Only }\end{array}$ & Osteomalacia & $\begin{array}{c}\text { Osteitis } \\
\text { Fibrosa and } \\
\text { Osteomalacia }\end{array}$ & $\begin{array}{l}\text { Osteitis } \\
\text { Fibrosa }\end{array}$ \\
\hline $\begin{array}{l}\text { Normal } \\
\text { Osteitis fibrosa } \\
\text { Osteoporosis.. } \\
\text { Osteosclerosis } \\
\text { Osteomalacia + } \\
\text { osteitis fibrosa }\end{array}$ & $\begin{array}{l}\ldots \\
\cdots \\
\cdots \\
\ldots\end{array}$ & $\begin{array}{r}19 \\
14 \\
2 \\
1 \\
1\end{array}$ & $\frac{9}{=}$ & $\frac{2}{1}$ & $\begin{array}{r}2 \\
6 \\
1 \\
- \\
1\end{array}$ & $\begin{array}{r}6 \\
8 \\
1 \\
- \\
-\end{array}$ \\
\hline Total & & 37 & 9 & 3 & 10 & 15 \\
\hline
\end{tabular}

patients, all of them with a documented history of renal failure of 12 months or less.

The relation between radiological and histological findings in 37 patients is shown in table V. Osteomalacia was diagnosed by radiological findings in only one of these patients, even though it was present histologically in 13. Whenever osteitis fibrosa was diagnosed radiologically it was also present on histology. However, 8 out of 19 patients with normal $x$-ray appearances were shown to have histological changes of osteitis fibrosa.

The correlation between serum calcium levels at the time of the biopsy and the presence and severity of osteomalacia is shown in fig. 2. All patients with osteoid indices of $2.0 \%$ or more had serum calcium levels of $8.5 \mathrm{mg} / 100 \mathrm{ml}$ or less. The presence and severity of osteitis fibrosa could not be statistically related

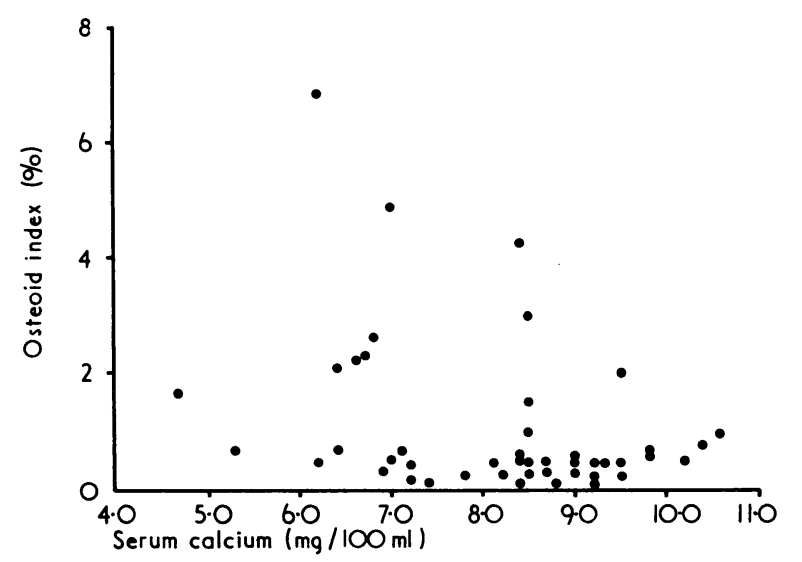

FIG. 2-Correlation between serum calcium on day of skeletal biopsy and osteoid index seen in undecalcified sections. All patients with osteoid indices of $2.0 \%$ or more had serum levels of $8.5 \mathrm{mg}$ or less per $100 \mathrm{ml}$. to serum calcium levels. There were three patients with serum calcium levels of $10 \cdot 1-10.6 \mathrm{mg} / 100 \mathrm{ml}$. All three had demonstrable osteitis fibrosa, two of them severe. No correlation could be established between the serum inorganic phosphate and serum bicarbonate on the one hand and the type or severity of the skeletal changes on the other. At the time of biopsy the serum alkaline phosphatase was raised to $18 \mathrm{King}$-Armstrong units or more per $100 \mathrm{ml}$ in four patients. The enzyme was of skeletal origin in each case (Posen et al., 1965) and each of these four patients had osteomalacia (alone or in combination with other lesions).

\section{Discussion}

Our findings indicate that $72 \%$ of patients with end-stage renal failure have some form of histological bone disease before the commencement of dialysis. Qualitative abnormalities (as distinct from volume changes) are more liable to occur in women, in patients with pyelonephritis, and in patients whose disease has been manifest for more than 12 months. The predominant histological lesion is osteitis fibrosa while osteomalacia occurs in less than a third of patients.

It has been suggested (Lumb et al., 1971) that there are geographical variations in the prevalence of osteomalacia among patients with renal failure. Our experience is parallel to that of Kaye et al. (1969) in Canada, who found osteomalacia in seven of 19 unselected patients with untreated renal failure. Haust et al. (1964) found a similar prevalance of osteomalacia in undialysed children with renal failure coming to necropsy. Garner and Ball (1966) who found histological osteomalacia in 16 out of 18 patients with renal failure and who did not encounter any patients with osteoporosis, give no indication how their patients were selected for biopsy. Follis and Jackson (1943), who performed necropsies on 39 adults dying in renal failure, found osteomalacia in half their patients and osteitis fibrosa in one third. The same group of workers, however, also found osteomalacia in $50 \%$ of all children coming to necropsy (Follis et al., 1943), suggesting that the "high prevalence" of osteomalacia among their renal patients was due, at least in part, to a background of osteomalacia among the population they studied.

This work leaves a number of problems unanswered. If, as has been stated (Parfitt, 1972), all patients who develop significant osteodystrophy go through a phase of osteomalacia the evidence for this statement has certainly disappeared in most patients with osteodystrophy of end-stage renal failure. We do not know why some patients develop more severe bony lesions than others, nor do we know why different types of skeletal lesions predominate in different patients.

None of our patients had received calcium or vitamin $D$. Protein restriction and aluminium hydroxide had been prescribed in a number of patients but not under metabolic supervision. None of the patients in this study was bed-ridden though most had severely restricted their physical activities during the period immediately preceding this study. The role of immobilization and dietary factors thus awaits further study. We are also investigating 15 patients with osteodystrophy out of proportion to the degree of their renal failure. These will be reported on in a separate communication.

We wish to thank Dr. F. C. Neale, who performed most of the biochemical determinations, Dr. J. Wright, who carried out the radiological examinations, and Miss Ruth Monk, who cut and stained most of the sections. Drs. M. Kleerekoper, R. Garrick, and A. W. Ireland helped to obtain biopsy specimens. Gay Hopkins and Gai Hume gave valuable secretarial help. This work was supported by grants from the Australian Kidney Foundation, from the N.S.W. State Cancer Council, and from the University of Sydney Cancer Research Fund. 


\section{References}

Blackman, J. E., Gibson, G. R., Lavan, J. N., Learoyd, H. M., and Posen, S. (1967). British Medical foumal, 2, 800 .

British Medical fournal, 1971, 2, 61 .

Claireaux A E (1953). Fournal of Pathology and Bacteriology, 65, 291

Cohen, M. E. L., Cohen, G. F., Ahad, V., and Kaye, M. (1970). Clinical Radiology, 21, 124.

Follis, R. H., and Jackson, D. A. (1943). Bulletin of the fohns Hopkins Hospital, 72, 232.

Follis, R. H., Jackson, D., Eliot, M. M., and Park, E. A. (1943). American Fournal of Diseases of Children, 66, 1 .

Garner, A., and Ball, J. (1966). Fournal of Pathology and Bacteriology, 91, 545. Garrick, R., Doman, $\dot{\mathbf{P}}_{\text {., }}$ and Posen, S. (1972). Clinical Science, 53, 789.

Garrick, R., Ireland, A. W., and Posen, S. (1971). Annals of Internal Medicine, 75, 221.

Hall, M. C., Elmore, S. E., Bright, R. W., Pierce, J. G., and Hume, D. (1969). Fournal of the American Medical Association, 208, 1825.

Harrington, K. D., Murray, W. R., Kountz, S. L., and Belzer, F. O. (1971). fournal of Bone and foint Surgery, 53A, 203.

Haust, M. D., Landing, B. H., Holmstrand, K., Currarino, G., and Smith, B. S. (1964). American fournal of Pathology, 44, 141.

Heptinstall, R. H. (1968). American fournal of Medicine, 44, 656

Hocking, D. R. (1964). Medical fourmal of Australia, 2,915.

Jennis, F., Lavan, J. N., Neale, F. C., and Posen, S. (1970). British fournal of Urology, 42, 511 .

Johnson, J. W., et al. (1971). Fournal of the American Medical Association, 215, 478.
Jowsey, J., Johnson, W. J., Taves, D. R., and Kelly, P. J. (1972). Fournal of Laboratory and Clinical Medicine, 79, 204.

Katz, A. I., Hampers, C. L., and Merrill, J. P. (1969). Medicine, 48, 333.

Kaye, M., Chatterice, G., and Cohen, G. F. (1969). Proceedings of the Fourth International Congress of Nephrology, Stockholm, 3, 151.

Kleeman, C. R., Massry, C. G., Coburn, J. W., and Popovtzer, M. M. (1969). Archives of Internal Medicine, 124, 262.

Lavan, J. N., Benson, W., Gatenby, A. H., and Posen, S. (1966). Medical fournal of Australia, 2, 694.

Lucas, R. C. (1883). Lancet, 1, 993.

Lumb, G. A., Mawer, E. B., and Stanbury, S. W. (1971). American fournal

O'Riordan, J. L. H., et al. (1970). Quarterly fournal of Medicine, 39, 359.

Parfitt, A. M. (1972). Orthopedic Clinics of North America, 3, 681.

Perkoff, G. T. (1967). New England Yournal of Medicine, 277, 129.

Posen, S., Neale, F. C., and Clubb, J. S. (1965). Annals of Internal Medicine,

62, 1234. Australia, 1, 421

Shapiro, R. (1971). American fournal of Roentgenology, 111, 750.

Siegelman, S. S. (1970). In Osteoporosis, ed. U. S. Barzel, p. 68. New York, Grune and Stratton.

Stanbury, S. W. (1957). British Medical Bulletin, 13, 57.

Stanbury, S. W. (1968). American fournal of Medicine, 44, 714.

Steinbach, H. L., et al. (1961). American fournal of Roentgenology, 86, 329.

Steinbach, H. L., and Noetzli, M. (1964). American fournal of Roentgenology, 9, 955 .

\title{
Diagnosis of Gonorrhoea in Women: Comparison of Sampling Sites
}

\author{
M. N. BHATTACHARYYA， A. E. JEPHCOTT, R. S. MORTON
}

British Medical fournal, 1973, 2, 748-750

\section{Summary}

A total of 250 women, 100 of them named contacts of men with gonorrhoea, were tested for infection. Each had prepared smear and culture specimens from urethra, endocervix, and vagina. The smears were Gram-stained and examined immediately. Cultures were taken using Stuart's transport medium with later inoculation of both selective and non-selective media for each specimen.

It was shown that examination of specimens from urethra and endocervix gave results superior to those found on examination of vaginal material alone. The study revealed that nearly one infected woman in three would have been missed if vaginal material only had been examined. Failure to secure a prompt scientific diagnosis has serious epidemiological implications.

Our results find support in the work of others. We conclude that the suggestion in some quarters that examination of vaginal material for the detection of gonococci is adequate should be abandoned. Any who feel unwilling to accept this view should at least supplement their testing with examination of urethral and endocervical specimens.

\section{Introduction}

Conflicting advice is offered by British gynaecological textbooks concerning the most appropriate sampling methods for the bacteriological diagnosis of gonorrhoea in women.

Royal Infirmary, Sheffield S6 3DA

M. N. BHATTACHARYYA, M.B., M.R.C.o.G., Senior Registrar, Department of Venereology

R. S. MORTON, F.R.C.P., Consultant Venereologist,

Public Health Laboratory, Sheffield S5 7AU

A. E. JEPHCOTT, M.B. M.R.C.PATH., Consultant Microbiologist
Stern (1963) said: "a swab should be taken high in the vagina and cultured." Willcox (1963), however, advised that urethral and cervical specimens be taken for microscopy and culture. Jeffcoate (1967), discussing acute salpingo-oophoritis, said: "cervical (or high vaginal) and urethral swabs" should be taken; though later, when commenting on the asymptomatic nature of early gonorrhoea, he advised preparation of urethral and endocervical smears and cultures. Peel and Brudenell (1969) advised the examination of cervical smears and cultures for the diagnosis of gonorrhoea but did not mention urethral sampling. Howkins and Bourne (1971) suggested urethral with either high vaginal or cervical swabbing, though Nicol (1971) specified the urethral and cervical sites only. Baird (1969) mentioned smears and cultures but did not specify sites to be tested.

Textbooks for nurses show the same dichotomy. Catterall (1964) advised urethral and cervical examinations, while in contrast textbooks offered to student nurses in midwifery (Hallam, 1972) and gynaecology (Dodds, 1967) support the taking of vaginal swabs.

It is to be expected that the confusion of opinion expressed in these textbooks will be reflected in clinical practice. Moreover, the situation has now become further complicated by the availability of new laboratory techniques with more sophisticated ways of overcoming contamination, which could possibly make the vaginal specimen more acceptable.

To resolve these uncertainties and to establish how useful in fact the vaginal specimen can be in present circumstances, a trial was carried out comparing it with more appropriate urethral and cervical specimens.

\section{Material and Methods}

The study covered 250 women who attended the special clinic, Royal Infirmary, Sheffield, between February and August 1972.

Group 1 consisted of 150 patients, of whom 50 were named sex partners of men with gonorrhoea. Group 2 consisted of 100 patients, 50 of whom were named contacts of gonorrhoea. The patients were in no way selected, and represent in terms of age and marital status the population of the clinic. 